\title{
The Implications of the Hungarian Nation Policy in Central Europe Since 1989: Between Tension and Integration
}

\author{
LAURA ROYER \\ University of Glasgow
}

\begin{abstract}
Since its democratic transition in the early nineties, Hungary has developed a foreign policy strategy, directed at Hungarian minorities abroad, known as 'nation policy' (nemzetpolitika). This nation policy can be conceptualised as a set of symbolic, financial, and political measures, and discourses directed at the Hungarian historical communities residing outside of the Hungarian state, aiming to strengthen Hungarian culture, language and influence in the Carpathian Basin.

In this paper, I seek to set out and analyse the implications of the Hungarian nation policy in Central Europe. After providing historical and conceptual background, I will argue that the Hungarian nation policy has in fact had contradictory outcomes in Central Europe, sometimes leading to confrontation with Hungary's neighbours, while at other times instigating dialogue, integration and development. Ultimately, I will call upon critical perspectives, highlighting the challenges and limits of this governmental strategy.
\end{abstract}

\section{INTRODUCTION}

On 4 October 2018, Ukraine decided to expel the Hungarian consul of Berehove, a city located in the Zakarpattia Oblast, Western Ukraine. A few hours later, the Hungarian government retaliated, expelling a Ukrainian diplomat.1 This diplomatic incident represented the peak of tensions initially triggered by a law passed in Ukraine in 2017. This law, known as the education law, aims at reinforcing the teaching of Ukrainian language in the schools of the country, to the detriment of the numerous minority languages of Ukraine, including Hungarian. The news had been coldly received by the Hungarian government, which, repeating its commitment to the protection of the rights of the Hungarian minorities abroad, started using all the tools at its disposal to pressure the Ukrainian government to remove the law. After a series of twists which

1 Ukraine, Hungary In Diplomatic Tit-For-Tat Expulsions Amid Passport Dispute', Radio Free Europe/Radio Liberty, 4 October 2018 < https://www.rferl.org/a/ukraine-expels-hungarian-consul-amid-passportrow/29525193.html> [accessed 26 March 2019]. 
had led the two states grow weary of each other, a video showing a citizenship ceremony taking place in the Hungarian consulate of Berehove leaked in September 2018.2 In fact, the video suggested that the consulate handed over Hungarian passports to members of the Ukrainian Hungarian minority, contravening the Ukrainian law, which forbids dual citizenship - ultimately leading to the aforementioned diplomatic crisis.

The situation may seem odd to those unaware of the existence of Hungarian minorities beyond the Hungarian state, nor of the Hungarian foreign policy strategy since the 1990s towards these minorities. This foreign policy strategy, henceforth called 'Hungarian nation policy', has triggered numerous tensions with Hungary's neighbours over the last thirty years, as illustrated by the Ukrainian case. Yet, it also paradoxically inspired cooperation and led to developments in the Central European region.

I will seek here to set out and analyse the implications of the Hungarian nation policy in Central Europe, encompassing Hungary, Slovakia, Serbia, Ukraine and Romania. I will first give a brief historical account of the Hungarian minorities in the Carpathian basin, and present an overview of the Hungarian nation policy since the democratic transition in the early nineties. Then, I will argue that the Hungarian nation policy has in fact had contradictory outcomes in Central Europe, sometimes leading to confrontation with Hungary's neighbours, while at other times instigating dialogue, integration and development. Eventually, I will call upon critical perspectives, highlighting the challenges and limits of this governmental strategy.

\section{THE HUNGARIAN NATION POLICY (NEMZETPOLITIKA): ORIGINS AND DEVELOPMENTS}

In a foreign policy document dating back to 1921, a Hungarian diplomat declared that: though they [Hungarian policy-makers] did not think of making the revision of the Trianon treaty their programme, they ought to try to render valid the rights and prerogatives assured them by the treaty, particularly the minorities' rights of their kindred in the territories severed from Hungary.3

2 Aleksei Arunyan, 'How Hungary and Ukraine Fell out over a Passport Scandal', Open Democracy, 11 October 2018

<https://www.opendemocracy.net/en/odr/how-kyiv-and-budapest-fell-out-over-zakarpattya/> [accessed 26 March 2019].

3 C School of Slavonic and Eastern European Studies, University College London, 2019. 
This set the pace for Hungarian foreign policy of the forthcoming century. The will to provide support to the Hungarian minorities living outside Hungary's borders has been a permanent feature in Hungarian politics since the end of the First World War, and remains a guiding line in contemporary foreign policy strategy.

In the aftermath of the First World War, the Treaty of Trianon was signed on 4 June 1920 between the Allies and the defeated Kingdom of Hungary. As expressed by Wilson, the fundamental principle underlying the redefinition of the European states' borders was the right to self-determination. Nevertheless, this principle caused problems in multi-ethnic Central and Eastern Europe: turning territories into nation-states in such an ethnically diverse region was tantamount to an impossible mission. As a result of Trianon, Hungary lost two-thirds of its historical territory and over half of its multi-ethnic population, while one third of Magyars (ethnic Hungarians) found themselves outside of the new borders, mostly in Romania but also in Croatia, Yugoslavia, Czechoslovakia and Ukraine.4

The treaty came as a diktat for the newly born Hungarian state. Hungary had lost the war and foreign powers had decided of its fate without consulting it. Worst, the new geographical division of Europe had also led to the division of the Hungarian nation. Nourishing hopes of reunification, the Hungarian government decided to side with Nazi Germany during the Second World War, which lead to another defeat.5

During the socialist era (1959-1989), while Trianon was arguably enduring in the Hungarian collective memory, nationalist claims were played down at the state level in the name of the 'communist brotherhood'. However, from the late seventies, and following the anti-Hungarian repression orchestrated by Ceausescu's Romania, the Hungarian government gradually beganto express concern about the fate of its kin-nationals again.6 As Pogonyi points out, the sensitivity of the topic amongst the Hungarian population allowed the political opposition to use it in order to contest the Communist rule.7

In 1989, the Hungarian Constitution was amended to include a reference to the Hungarian minorities abroad8: 'the Republic of Hungary bears a sense of responsibility for the fate of

\footnotetext{
4 Lonnie R. Johnson, 'World War I and National Self-Determination, 1914-1922', in Central Europe:

Enemies, Neighbors, Friends (Oxford: Oxford University Press, 1996), pp. 191-96.

5 Pál Pritz, 'Hungarian Foreign Policy between Revisionism and Vassalage', Foreign Policy Review, 2011, pp. $98-$ 105.

6 Julian Duplain, Ethnic Hungarian Minorities in Central and Eastern Europe (WRITENET, 1 June 1996)

<http://www.refworld.org/docid/3ae6a6c34.html> [accessed 26 March 2019].

${ }_{7}$ Szabolcs Pogonyi, Extra-Territorial Ethnic Politics, Discourses and Identities in Hungary, Palgrave Studies in Citizenship Transitions, (Palgrave Macmillan, 2017), p. 111.

8 Nowadays, there are approximately 1,200,000 Hungarians in Romania, 460,000 in Slovakia, 250,000 in Serbia, 150,000 in Ukraine, and smaller communities in Croatia, Austria and Slovenia, meaning that the Hungarian minorities abroad represent at least 2,000,000 people. As for comparison, there are about 10,000,000 citizens in
} 
Hungarians living outside its borders and shall promote and foster their relations with Hungary'.9 Prime Minister Jószef Antall's famous declaration one year later only confirmed the path the country thenceforth adopted: 'I want to act as the head of the government of all the citizens of this 10 million strong country, but in spirit and sentiment as the prime minister of 15 million Hungarians'.10 From then on, one of the pillars of the Hungarian foreign policy has been the socalled nation policy (nemzetpolitika).

This aimed to 'preserve Hungarian culture and feed a trans-border sense of cohesion among all those who regard themselves as Hungarian'.11 It will be understood here as a set of symbolic, financial, political measures and discourses directed at the Hungarian historical communities residing outside of the Hungarian state, seeking to strengthen Hungarian culture, language and influence in this near-abroad.

The nation policy has slowly evolved throughout the last three decades, shaped by different political interests. In 2001, the first Fidesz-led government (1998-2002) passed the 'Status Law',12 offering visa- free entry, employment and educational opportunities to ethnic Hungarians living abroad - provoking turmoil in the neighbouring states 13 and criticism from the EU (of which Hungary was not a member at the time). The Status Law was subsequently amended when the Left came to power in 2002, prioritising EU accession and good neighbourly relations.14 While the successive left-wing governments (2002-2010) did not prioritise the question of the Hungarians abroad in shaping foreign policy, right-wing parties Jobbik, and soon Fidesz in an attempt to counter Jobbik's increasing support) consistently foregrounded the matter. Thus, when Fidesz came back to power in 2010, it immediately promulgated an Act on Citizenship, facilitating the acquisition of Hungarian citizenship to ethnic Hungarians living in neighbouring states.15 The act was furthermore completed in 2011 with a new Act on the Elections of Members of Parliament of Hungary, allowing non-resident Hungarian citizens to

\footnotetext{
Hungary. See Balázs Kapitány, 'Ethnic Hungarians in the Neighbouring Countries', in Demographic Portrait of Hungary, 2015.

9 Quoted in Eamonn Butler, 'Hungary and the European Union: The Political Implications of Societal Security Promotion', Europe-Asia Studies, 59.7 (2007), p. 1120.

10 József Antall, Prime Minister of Hungary: Selected Speeches and Interviews, ed. by Géza Jeszenszky (Antall József Alapítvány, 2008) <https://www.martenscentre.eu/sites/default/files/publication-files/antall_jozsef.pdf> [accessed 26 March 2019], p. 29.

11 Anita Sobják, The Implications of Hungary's National Policy for Relations with Neighbouring States (The Polish Institute of International Affairs, June 2012), p. 1.

12 Pogonyi, p. 2.

13 'Hungary “Status Law” Irks Neighbours', BBC News, 19 June 2001

<http://news.bbc.co.uk/2/hi/world/monitoring/media_reports/1397385.stm> [accessed 26 March 2019].

14 'Amended Hungarian Status Law Fails to Quiet Critics', Euractiv, 7 January 2003

$<$ https://www.euractiv.com/section/enlargement/opinion/amended-hungarian-status-law-fails-to-quiet-critics/> [accessed 26 March 2019].

15 Pogonyi, pp. 86-87.
} 
vote for and to be elected on national party lists, 16 while in the same year, the new Hungarian Constitution put forward by the government went a step further by formally taking on responsibility for Hungarian kin-nationals:

Bearing in mind that there is one single Hungarian nation that belongs together, Hungary shall bear responsibility for the fate of Hungarians living beyond its borders, shall facilitate the survival and development of their communities, shall support their efforts to preserve their Hungarian identity, the effective use of their individual and collective rights, the establishment of their community selfgovernments, and their prosperity in their native lands, and shall promote their cooperation with each other and with Hungary.17

Eventually, the government published a strategy document in 2013, the Policy for Hungarian Communities Abroad: Strategic Framework for Hungarian Communities Abroad, ${ }^{18}$ providing financial, political and symbolic support to the Hungarian communities abroad and thereby seeking the preservation of the Hungarian culture against perceived threats of assimilation and dilution.

\section{A CENTRAL European PANDORA's box?}

Since the early nineties, the Hungarian nation policy has triggered frequent quarrels between Hungary and its neighbours. The laws promulgated by Hungary as part of its nation policy have often been perceived by the neighbouring states as intrusive and interfering in their national affairs. For example, following the 2010 Act on Citizenship, Slovakia vigorously reacted and passed a counter-act nullifying the Slovak citizenship status for those of its Hungarian minority applying for Hungarian citizenship, in order to deter what was perceived as a possible treason.19 Another example can recently be found with the Ukrainian case mentioned earlier. In September 2017, when Ukraine passed a law enforcing the use of the Ukrainian language from the secondary

16 Ibid., p. 96.

17 Article D, The Fundamental Law of Hungary, 2011,

<http://www.kormany.hu/download/e/02/00000/The\%20New

\%20Fundamental\%20Law\%20of\%20Hungary.pdf> [accessed 26 March 2019].

18 Pogonyi, p. 98.

19 Anita Sobják, The Implications of Hungary's National Policy for Relations with Neighbouring States (The Polish Institute of International Affairs, June 2012), p. 4. 
school to the disadvantage of the minority languages, Hungarian Minister János Lázár declared that 'Ukraine is losing one of its friends',20 whereupon the Hungarian government started blocking NATO meetings with Ukraine, endangering the resolution of the Ukrainian crisis.21 The situation recently escalated further, with the two countries mutually expelling diplomats in October 2018.

Moreover, the Hungarian minority issue has become a highly politicised topic, both in Hungary and abroad. At the Hungarian domestic level, the Antall's statement of the early nineties created a precedent, and no politician can avoid mentioning the issue nowadays, at the risk of creating political vacuum for opponents to dive into.22 Sobják also mentions that 'national policy is one of the fields in which Fidesz has achieved the relatively homogeneous approval of the electorate'.23 As Viktor Orbán was re-elected for a third consecutive term in April 2018, he most likely will not neglect this fruitful strategy in the future. Outside of the Hungarian state, the minority parties have also benefited from the Hungarian government's support and do not hesitate to play this card when they believe that their interests are threatened. As an example, when the Romanian government passed a law in 1995, prioritising the use of the Romanian language in schools, the Democratic Alliance of Hungarians in Romania (RMDSZ/UDMR)24 denounced a forced 'romaniasation' and reached out to Budapest in order to pressurise the Romanian government.25

However, the Hungarian nation policy does not always lead to direct confrontation, partly because the Central European states are interdependent. While Hungary needs its neighbours' support for the protection of the Hungarians abroad, all the surroundings states have interest in keeping Hungary on their side. Slovakia and Romania may definitely benefit from the 'popularity' and the mobilisation capacities of Viktor Orbán at the European level to channel their own agenda, while Ukraine and Serbia, members of neither NATO or the EU, are very dependent on Hungarian support for their integration into the Euro-Atlantic alliance. Forinstance, the Serbian parliament voted for a restitution law in September 2011, aimed at returning the goods confiscated by the communist power after the Second World War. However, this provision was

\footnotetext{
20 'The Government Will Do Everything to Protect Hungarian Interests', Ministry of Foreign Affairs and Trade, 21 September 2017 <http://www.kormany.hu/en/prime-minister-s-office/news/the-government-will-do-everythingto-protect- hungarian-interests $>$ [accessed 26 March 2019].

21 'U.S., NATO Urge Hungary, Ukraine To Settle Language-Law Dispute', Radio Free Europe/Radio Liberty, 14 February 2018 < https://www.rferl.org/a/us-nato-urge-hungary-ukraine-settle-language-law-dispute-blocking-natomeeting- ministerial/29038565.html> [accessed 26 March 2019].

22 Butler, p. 1121.

23 Sobják, p. 8.

24 The RMDSZ/UDMR is a minority party which seeks to represent the interests of the Romanian Hungarian minority. It has participated to several governmental coalitions since 1990 .

25 Duplain.
} 
ROYER - THE IMPLICATIONS OF THE HUNGARIAN NATION POLICY IN CENTRAL EUROPE SINCE 1989: BETWEEN TENSION AND INTEGRATION

supposed to be non-applicable to states such as Hungary, who are seen as Yugoslavia's Second World War enemies. As a result, the members of the Serb Hungarian minority could not claim back their properties. As the Hungarian government threatened to block Serbia's EU accession, the country agreed to revise the law and the problem was resolved, all in all, quite smoothly.26 The Central European governments believe that a win-win compromise is always preferable to a bold confrontation,27 and their interdependence ensures a form of diplomatic equilibrium.

\section{DEMOCRACY, INTEGRATION AND DEVELOPMENT: THE (IN)DIRECT CONSEQUENCES OF THE HUNGARIAN NATION POLICY IN CENTRAL EUROPE}

Furthermore, the nation policy upheld by Hungary since the early nineties has arguably, and perhaps paradoxically, contributed to the democratic, political and economic development of the Central European region. First, Hungary has always actively promoted the Euro-Atlantic integration of the whole region, as its 'national interests may be asserted not only through national means but also in the framework of Euro-Atlantic cooperation'.28 The country became part of the Council of Europe in 1990, joined the OECD in 1996, NATO in 1999 and the EU in 2004. In that regard, it used to behave as one of the 'good students' of Central Europe, fully embedded into the Euro-Atlantic system of cooperation. Butler showed that this eagerness can be understood in relation to the Hungarian nation policy.29 Indeed, Hungary proved very early to consider its membership to international organisation as a tool to promote minority rights and to pressurise its neighbours on such issues. Significantly, the Hungarian government relies on traditional minority rights defenders such as the Council of Europe or the OSCE in order to benefit from their provisions on minority rights, soliciting their support when it acknowledges an issue with its kin-nationals.30 It also embraced the EU as another tool to improve the situation of its kin-minorities: ' $[\mathrm{b}] \mathrm{y}$ championing fundamental rights, including the promotion of minority

\footnotetext{
26 See for example 'Serbia Finds Deal with Hungarians over Restitution', 21 October 2011

$<$ https://www.eubusiness.com/news-eu/serbia-hungary-wwii.d1b> [accessed 26 March 2019].

27 See for example 'Hungary and Serbia Have a Mutual Interest in Each Other's Success', Ministry of Foreign Affairs and Trade, 13 April 2017 <http:/ /www.kormany.hu/en/ministry-of-foreign-affairs-and-trade/news/hungary-andserbia- have-a-mutual-interest-in-each-other-s-success> [accessed 26 March 2019].

28 'Hungary's National Security Strategy' (Ministry of Foreign Affairs of Hungary, 2012), p. 6.

29 Butler.

30 On the recent Ukrainian education law, see for example 'The OSCE High Commissioner Also Shares Our Concerns', Ministry of Foreign Affairs and Trade, 24 October $2017<\mathrm{http}: / /$ www.kormany.hu/en/ministry-offoreign-affairs-and- trade/news/the-osce-high-commissioner-also-shares-our-concerns> [accessed 26 March 2019].
} 
rights in CEECs through accession negotiations and the stability pact, and by passing antidiscriminatory legislation, the EU offers, albeit indirectly, some form of societal security'.31

Moreover, because EU membership lifts borders within the Union through the Schengen Agreement, it allowed 'Hungary's borders to become spiritualised, thus healing, albeit metaphorically, the legacy of Trianon'.32 In order to reach a form of reunification of the Hungarian nation, Hungary has pushed the neighbouring states to become EU members. It has always actively lobbied to support Serbia's integration in the EU, and used to sustain excellent relations with Ukraine before the education law. Therefore, as joining the EU implies certain democratic standards and an open market economy,33 the Hungarian nation policy indirectly supports the democratisation of the Central European states.

Lastly, the Hungarian nation policy promotes the economic development of Hungary's neighbouring states through subsidies and economic support. Indeed, the Hungarian government does not necessarily want the Hungarian minorities to 'come back home', because receiving a large flow of immigrants would require increased expenditure on welfare services. The Hungarian government also believes that the historical lands of Hungary must remain populated with Hungarians.34 As a consequence, the Hungarian power has had to find a way to balance this dual objective: improving its kin-minorities' life standards, while making sure that they will not settle back in Hungary. One strategy that has been developed is the promotion of temporary residences of foreign Hungarians to Hungary. These measures, besides fuelling Hungary's economy, also improve migrants' economic standing and reinforces their cultural and relational ties with their 'motherland'. 35 Another strategy is to support directly the Hungarians abroad through cultural projects, or indirectly the neighbouring states through economic and social development support.36 A Hungarian official explains: 'the political consolidation of the nonEU-member countries can be reached by their social-economic consolidation. This can be done with the strengthening of economic ties, creating new jobs by investments [...] The link between foreign policy and economy, in this sense, could not be stronger'. ${ }^{37}$ As an example, the Motherland programme was implemented in 2004 to foster economic exchanges and investment at a regional level.38 Hungarian investments have been particularly important in Ukraine: as for 2016,

\footnotetext{
31 Butler, p. 1129.

32 Ibid., p. 1130. Emphasis in the original.

33 'Conditions for Membership', European Commission, $2016<$ https://ec.europa.eu/neighbourhood-

enlargement/policy/conditions-membership_en> [accessed 26 March 2019].

34 Butler, p. 1125.

35 Ibid., p. 1126.

36 Ibid., p. 1138.

37 Quoted in László Póti, 'Hungarian Foreign Policy and ENP in the East: Energy- (and) Nationality-Based Policy', International Issues \& Slovak Foreign Policy Affairs, XV.3-4 (2006), pp. 72-73.

38 Ibid., p. 70.
} 
Hungary was the 7th biggest investor in Ukraine (4.3\%).39 When the tensions with Ukraine occurred, Sziijjártó used these economic investments as a bargaining tool to obtain guarantees that the situation would be resolved.40

\section{CRITICAL PERSPECTIVES}

After reviewing the implications of the Hungarian nation policy for Central Europe, I would now like to call upon critical perspectives on the concept. First, while the Hungarian nation policy is undoubtedly a big part of the foreign policy strategy of Hungary, the relations it sustains with its neighbours cannot be reduced to this aspect. Indeed, the country needs partners to really be influential on the European or international stages. As such, the development of the Visegrád cooperation (V4) addresses the geopolitical weaknesses of the region. This partnership with Poland, Slovakia and the Czech Republic has proved to be very successful in providing a counter power to Western European countries, notably during the refugee crisis. However, for the alliance to be efficient, Hungary had and will have to put aside its disagreements with Slovakia. In 2006 already 'when the Hungarian and Slovak prime ministers had a quarrel, he [Prime Minister Ferenc Gyurcsány] pointedly noted: the four prime ministers adopted an unequivocal agreement that they would continue cooperation within the Visegrád group, irrespective of bilateral disputes'.41 In relation to Romania, Sobják noted in 2012 that the relations between the two countries had substantially improved, although Romania could have resented Hungary's actions concerning the Act on Citizenship. She explains this improvement with the fact that the two countries had adopted common positions on a wide range of issues. In fact, Hungary and Romania have interest in co-operating at the European level than undermining their positions with regional quarrels. Moreover, 'good communication between the two centre-right governments (both members of the European People's Party) and in particular between Romanian President Traian Băsescu and Hungarian Prime Minister Viktor Orbán, also

\footnotetext{
39 And the second of the region after Russia. See 'Ukraine - 9.4-Foreign Direct Investment \& Foreign Portfolio Investment Statistics', Export.Gov, 2017 < https://www.export.gov/article?id=Ukraine-foreign-direct-investmentstatistics> [accessed 24 April 2018].

40 'It Is Our Firm Expectation with Regard to Ukraine That It Must Guarantee the Rights of the Hungarian Minority', Ministry of Foreign Affairs and Trade, 13 April 2017 <http://www.kormany.hu/en/ministry-of-foreignaffairs-and- trade/news/it-is-our-firm-expectation-with-regard-to-ukraine-that-it-must-guarantee-the-rights-of-thehungarian- minority> [accessed 26 March 2019].

41 Judit Hamberger, 'Hungarian The Future of the Visegrad Cooperation from the Hungarian Perspective', International Issues \& Slovak Foreign Policy Affairs, XV.3-4 (2006), p. 96. Emphasis added.
} 
contributed to cordial relations'.42 This analysis illustrates that conflicts over kin-nationals are also intertwined with more pragmatic political considerations and alliances. Subsequently, Hungary's ardours with regard to its kin-nationals are likely to be tempered if it needs to join forces to address other important topics.

What is more, it is interesting to ask whether the 'minority argument' is not as well a potential political smokescreen to achieve other goals. Orbán has proved to be a pragmatic political leader and is currently sustaining a difficult balance, where he seeks to preserve allies in the West while opening up to friendships in the East, notably with Russia. When it comes to the Ukrainian case, the question becomes particularly relevant. Indeed, the Ukrainian education law above cited is the result of the war in Ukraine: the Ukrainian state was targeting as a priority the Russian-speaking minorities living in the country, and the Hungarian-speaking communities appear to haven been 'collateral damage'. Thus, the violent reaction of the Hungarian state, blocking Ukrainian discussion with its Western partners, could perhaps be interpreted as a friendly signal towards Russia, punishing Ukraine and slowing down its Western rapprochement without openly discrediting itself vis-à-vis its NATO partners, and sticking to its traditional role of protector of the Hungarian minorities. On her blog, Hungarian Spectrum, Eva S. Balogh even went a step further, suggesting that the Hungarian government held irredentist aims:

Viktor Orbán is convinced that sooner or later Ukraine will have to settle for being part of the Russian sphere of interest. Since Orbán is convinced that Ukraine will never belong to the European Union and NATO, especially if he has anything to do with it, Kiev will have no choice but to settle its differences with Moscow and be satisfied with its status as a client state of Russia. That development most likely would be accompanied by ceding territories to Russia in the East. In that case, Orbán figures, he might be able to put in a bid for a small strip of territory where about 100,000 Hungarian speakers currently live.43

In any case, it is certain that the current Hungarian blocking of NATO talks with Ukraine serves, be it indirectly, Russian interests.

How successful the Hungarian nation policy will remain is also uncertain. The bad relations Hungary currently sustains with its Western partners may have consequences on its leverage power, and therefore on the fate of the Hungarian minorities abroad. The refugee crisis

42 Sobják, pp. 5-6.

43 Eva S. Balogh, 'What Is Hungary after in Ukraine?', Hungarian Spectrum, 2018

$<$ https://hungarianspectrum.org/2018/09/26/what-is-hungary-after-in-ukraine/> [accessed 26 March 2019]. 
and the way it was handled by the Hungarian government has left a bitter taste in the mouths of many European leaders. They have become weary of Hungary's infringements to the rule of law, ultimately leading to the adoption of the Sargentini report in the European Parliament in September 2018. Moreover, Orbán has witnessed over the last months the re-election of Angela Merkel in Germany (2018) and election of Emmanuel Macron in France (2017), two powerful pro-EU leaders that are likely not to be accommodating towards Hungary. Finally, Orbán's new friendship with Vladimir Putin surely will not be looked upon favourably by Hungary's allies in NATO and the EU.44 As Hungary proved to be very reliant on its partners to secure the rights of its kin-minorities, how the government will proceed if it alienates these partners remains an unanswered question.

\section{CONCLUSION}

In this paper, I examined the Hungarian nation policy's implications in Central Europe. In fact, the 'return to Europe' of Hungary in the early nineties was correlated with the (re)emergence of narratives asserting the indivisibility of the Hungarian nation. Since then, the different Hungarian governments have sought to defend not only the interests of the Hungarian citizens in Hungary but also of the ethnic Hungarians living in Romania, Slovakia, Serbia and Ukraine with the aim to preserve and defend Hungarian culture and language in the former Hungarian territories. This nation policy has led to numerous quarrels with the above-mentioned states and still occasionally threatens the equilibrium of the region. However, it has also had positive effects on the cohesion and the development of Central Europe, as Hungary believes that its kin-nationals are better off in a peaceful and democratic environment.

Interestingly, the government's concern for the Hungarian minorities abroad appears to fluctuate over time, seemingly depending on (geo)political circumstances. Especially since Fidesz's accession to power in 2010, the nation policy has increasingly been instrumentalised, or downplayed, to support other political interests that should perhaps not be overlooked. In this regard, future developments in the dispute between Hungary and Ukraine will surely be instructive.

44 Veronika Jóźwiak, Hungary’s Foreign Policy in a Changing International Environment (The Polish Institute of International Affairs, 29 March 2017) and 'Hungary's Place in the World in 2017', in Hungarian Politics in 2017, ed. by András Bíró-Nagy (Budapest: Friedrich-Ebert-Stiftung and Policy Solutions, 2018), pp. 33-44. 
ROYER - THE IMPLICATIONS OF THE HUNGARIAN NATION POLICY IN CENTRAL EUROPE SINCE 1989: BETWEEN TENSION AND INTEGRATION

\section{REFERENCES}

'Amended Hungarian Status Law Fails to Quiet Critics', Euractiv, 7 January 2003

$<$ https://www.euractiv.com/section/enlargement/opinion/amended-hungarian-status-lawfails-to- quiet-critics /> [accessed 26 March 2019]

Apponyi, Albert, 'Hungarian Foreign Policy', 1921

Arunyan, Aleksei, 'How Hungary and Ukraine Fell out over a Passport Scandal', Open Democracy, 11 October 2018 <https://www.opendemocracy.net/en/odr/how-kyiv-andbudapest-fell-out-over-

zakarpattya/> [accessed 26 March 2019]

Balogh, Eva S., 'What Is Hungary after in Ukraine?', Hungarian Spectrum, 2018

<https: / / hungarianspectrum.org/2018/09/26/what-is-hungary-after-in-ukraine/> [accessed 26 March 2019]

Bíró-Nagy, András, ed., 'Hungary's Place in the World in 2017', in Hungarian Politics in 2017 (Budapest: Friedrich-Ebert-Stiftung and Policy Solutions, 2018), pp. 33-44

Butler, Eamonn, 'Hungary and the European Union: The Political Implications of Societal Security Promotion', Europe-Asia Studies, 59 (2007), 1115-44

'Conditions for Membership', European Commission, 2016 $<$ https://ec.europa.eu/neighbourhood- enlargement/policy/conditionsmembership_en> [accessed 26 March 2019]

Duplain, Julian, Ethnic Hungarian Minorities in Central and Eastern Europe (WRITENET, 1 June 1996) $<$ http://www.refworld.org/docid/3ae6a6c34.html> [accessed 26 March 2019]

Hamberger, Judit, 'Hungarian The Future of the Visegrad Cooperation from the Hungarian Perspective', InternationalIssues \& Slovak Foreign Policy Affairs, XV (2006), 91-107

'Hungary and Serbia Have a Mutual Interest in Each Other's Success', Ministry of Foreign Affairs and Trade, 13 April $2017<$ http://www.kormany.hu/en/ministry-of-foreign-affairsand- $\quad$ trade/news/hungary-and-serbia-have-a-mutual-interest-in-each-other-ssuccess $>$ [accessed 26 March 2019]

'Hungary “Status Law” Irks Neighbours', BBC News, 19 June 2001

< http://news.bbc.co.uk/2/hi/world/monitoring/media reports/1397385.stm> [accessed 26 March 2019] 
ROYER - THE IMPLICATIONS OF THE HUNGARIAN NATION POLICY IN CENTRAL EUROPE SINCE 1989: BETWEEN TENSION AND INTEGRATION

'Hungary’s National Security Strategy' (Ministry of Foreign Affairs of Hungary, 2012)

'It Is Our Firm Expectation with Regard to Ukraine That It Must Guarantee the Rights of the Hungarian Minority', Ministry of Foreign Affairs and Trade, 13 April 2017

$<$ http://www.kormany.hu/en/ministry-of-foreign-affairs-and-trade/news/it-is-our-firmexpectation- with-regard-to-ukraine-that-it-must-guarantee-the-rights-of-thehungarian-minority $>$ accessed 26

March 2019]

Jeszenszky, Géza, ed., József Antall, Prime Minister of Hungary: Selected Speeches and Interviews (Antall József Alapítvány, $<$ https://www.martenscentre.eu/sites/default/files/publication-

files/antall_jozsef.pdf> [accessed 26 March 2019]

Johnson, Lonnie R., 'World War I and National Self-Determination, 1914-1922', in Central Europe: Enemies, Neighbors, Friends (Oxford: Oxford University Press, 1996), pp. 171-96

Jóźwiak, Veronika, Hungary's Foreign Policy in a Changing International Environment (The Polish Institute of International Affairs, 29 March 2017)

Kapitány, Balázs, 'Ethnic Hungarians in the Neighbouring Countries', in Demographic Portrait of Hungary, 2015

Pogonyi, Szabolcs, Extra-Territorial Ethnic Politics, Discourses and Identities in Hungary, Palgrave Studies in Citizenship Transitions, (Palgrave Macmillan, 2017)

Póti, László, 'Hungarian Foreign Policy and ENP in the East: Energy- (and) Nationality-Based Policy',

International Issues \& Slovak Foreign Policy Affairs, XV (2006), 64-75

Pritz, Pál, 'Hungarian Foreign Policy between Revisionism and Vassalage', Foreign Policy Review, 2011, 98105

‘Serbia Finds Deal with Hungarians over Restitution', 21 October 2011

$<$ https://www.eubusiness.com/news-eu/serbia-hungary-wwii.d1b > [accessed 26 March 2019]

Sobják, Anita, The Implications of Hungary's National Policy for Relations with Neigbbouring States (The Polish Institute of International Affairs, June 2012), pp. 1-9

The FundamentalLaw of Hungary, 2011

$<$ http://www.kormany.hu/download/e/02/00000/The\%20New

$\% 20$ Fundamental $\% 20 \mathrm{Law} \% 20$ of $\% 20$ Hungary.pdf $>$ [accessed 26 March 2019] 
ROYER - THE IMPLICATIONS OF THE HUNGARIAN NATION POLICY IN CENTRAL EUROPE SINCE 1989: BETWEEN TENSION AND INTEGRATION

'The Government Will Do Everything to Protect Hungarian Interests', Ministry of Foreign Affairs and Trade, 21 September $2017 \quad<$ http://www.kormany.hu/en/prime-minister-soffice/news/the-

government-will-do-everything-to-protect-hungarian-interests> [accessed 26 March 2019]

'The OSCE High Commissioner Also Shares Our Concerns', Ministry of Foreign Affairs and Trade, 24 October 2017 <http://www.kormany.hu/en/ministry-of-foreign-affairs-andtrade/news/the-osce-

high-commissioner-also-shares-our-concerns > [accessed 26 March 2019]

'Ukraine - 9.4-Foreign Direct Investment \& Foreign Portfolio Investment Statistics', Export.Gov, 2017

$<$ https://www.export.gov/article?id=Ukraine-foreign-direct-investment-statistics $>$ [accessed 24 April 2018]

'Ukraine, Hungary In Diplomatic Tit-For-Tat Expulsions Amid Passport Dispute', Radio Free Europe/Radio Liberty, 4 October 2018 <https://www.rferl.org/a/ukraine-expelshungarian-consul-

amid-passport-row/29525193.html > [accessed 26 March 2019]

'U.S., NATO Urge Hungary, Ukraine To Settle Language-Law Dispute', RadioFreeEurope/ RadioLiberty, 14 February $2018<$ https://www.rferl.org/a/us-nato-urge-hungary-ukraine-settlelanguage-law-

dispute-blocking-nato-meeting-ministerial/29038565.html > [accessed 26 March 2019]

This work is licensed under the Creative Commons Attribution-NonCommercial-ShareAlike 4.0 International License. To view a copy of this license, visit http://creativecommons.org/licenses/by-nc-sa/4.0/ or send a letter to Creative Commons, PO Box 1866, Mountain View, CA 94042, USA. 